\title{
Review of Roger E. Backhouse's The puzzle of modern economics: science or ideology? Cambridge: Cambridge University Press, 2010, 214 pp.
}

\author{
DAVID COLANDER \\ Middlebury College
}

Roger Backhouse is one of the most insightful observers of modern economics around. Thus, one can only welcome a new book by him on the economics profession. Despite my admiration of him, and perhaps because of my high expectations, I found The puzzle of modern economics a bit of a disappointment. Part of that disappointment could simply be that the book is written for multiple audiences, including both academic economists such as me who are inherently interested in the material he is discussing, and intelligent lay readers whose interests are more general and who need more background. Such multiple audiences create a representative reader who is between the two.

But my reaction can also in part be explained by a substantive difference I have with him on the story he is telling. This difference is not about what modern economics is-there I think we largely agree. The difference concerns how the profession got here. He, far more than I, sees pro-market ideological forces as the driving force in the evolution of economic thought. I see internal professional incentives, which led to a departure from the Classical methodology that required strict separation of science and policy, and the adoption of a methodology that blended science and policy. In my view, this combining of policy and science, initiated by pro-government activist economists, led to a reaction by pro-market economists and a hopeless intertwining of science and ideology by both groups.

The book consists of ten chapters divided into an introduction and three parts. The introduction begins with a discussion of some recent critiques and defenses of the economics profession, both by lay people and academic economists. While the nature of these differs, Backhouse blends them together into an overarching critique that economics is ideologically tainted. He suggests that the existence of these critiques suggest a puzzle about the profession. He asks how such different views of a field can exist. He writes: "Is economics the most rigorous of the 
social sciences, then, or little more than the expression of a free-market ideology?" (p. 14). For the intelligent lay person, his question probably has great interest, but for me it is a bit too general and diffuse. The economics profession is multidimensional and encompasses economists with many different views. It is rigorous in some ways, un-rigorous in others. It has inherent ideological aspects in some ways and is ideologically neutral in others. Given this multidimensionality, I am more surprised by the lack of effective critiques than I am by the existence of critiques.

Part I, "Economics in action", consists of four chapters that discuss examples of where economics has recently been applied to real-world problems. This includes the role of economics in creating new pollution markets, in creating market economies in formerly communist countries, in globalization, and in money and finance. These chapters seem directed at the interested lay person. They are overviews of general issues and do not break new ground. For example, in the "Money and finance" chapter, Backhouse first goes over the basics of derivatives and Black Scholes and then discusses the Long Term Capital Management incident and UK monetary policy history, rather than discussing new consensus in macroeconomics and the empirical use of the DSGE model by central banks, topics that would have been more relevant for his academic economic readership. Surprisingly, he spends very little time here discussing the most recent financial crisis, suggesting that since macroeconomic theory will be covered in a later chapter that discussion can be put off until then.

His conclusion from these chapters is that "economics is most successful where problems are narrowly defined and that its applications is most problematic when wider issues, involving politics or social phenomena, need to be considered" (p. 97). He further concludes from these case studies that "it would be wrong either to dismiss economics altogether [...] or to sweep such concerns aside" (p. 97). These conclusions are quite reasonable, but for academic economists interested in these issues, four chapters were unnecessary to arrive at them.

Part II, "Historical perspectives", is designed to allow the reader to see the bigger picture behind the case studies of the earlier chapters. Chapter 6 considers the history of microeconomics. It starts with a discussion of Lionel Robbins's definition of economic science, which Backhouse sees as an important statement of economic methodology, 
even though he agrees that economists have seldom followed this definition. He sees Robbins as a central figure in the evolution of economics to its current ideological structure. The lesson he draws from the chapter is that "many of the developments in thinking about microeconomics during the period since the Second World War need to be understood as the result of economists trying to be scientific" (p. 115).

Chapter 7 considers macroeconomics. It starts with an overview of the history of macroeconomics from the time of Keynes, and then discusses more recent macroeconomics in the last couple of pages. While this discussion is reasonable, it is somewhat less than the indepth consideration Backhouse seemed to promise when he dropped the issue of economists' role in the financial crisis in chapter 5.

The second two chapters of Part II return to the title theme: science and ideology. The first of these looks at how economics has evolved in its policy views from supporting a mixed economy from the 1940s to the 1960s, to supporting a free-market economy more recently. Backhouse suggests that economists who supported government intervention were looser in connecting ideology and their analysis than were those who supported free markets. It is here where my interpretation of the history differs from his. Backhouse sees the evolution as driven by pro-market economists leading the economics profession away from a non-ideological scientific approach. My interpretation of the history is different. In my view there can be no non-ideological scientific theory which leads to policy conclusions, and it was the largely pro-government activist economists' combining of economics and science, starting in the 1930s in both micro and macro, that first departed from the Classical methodology of strict separation of policy and science. It was this separation that Robbins was attempting to defend in his well known essay; I see Robbins's definition of economics as descriptive, not prescriptive, and Robbins's prescriptive path as being the path not followed by the profession.

Classical economists, and neoclassical economists who followed a Classical methodology, handled the ideological problem by accepting that their policy views were based on values, their reading of history, their intuition, and economic science. To keep the science of economics as value free as possible, they separated the policy branch of economics from the pure science of economics. Doing so admitted that any policy view necessarily had non-scientifically derivable value judgments underlying it. Policy discussions were placed in the art of economics: 
it was agreed that reasonable economists could agree about the science of economics even while disagreeing fundamentally about policy.

In the 1930s and 1940s this classical separation of art and science was abandoned, as economists started drawing policy conclusions directly from their models. Students began to be taught that economic science called for government intervention to correct externalities or to smooth out macro-fluctuations. Textbooks changed from teaching the wisdom of economists-broad arguments that integrated moral judgments, psychological insights, history, economic science, and common sense-to teaching the science of economics. The careful discussion of the limitations of models was lost, and students began to believe that policy followed directly from scientific models. This change in pedagogy is, in my view, central to the blending of ideology and economic science that currently exists.

The best of the scientific economists, such as Paul Samuelson, avoided the most flagrant connecting of scientific models and policy, but even they moved away from the careful qualifications of the formal models found in Mill, Marshall, and even Pigou. In the textbooks, the policy art and science of economics became blended into one. It occurred in both micro and macro, where Keynesian economic policy was presented as scientific, and Classical policy portrayed as ideologically motivated, or scientifically wrong. That provoked a reaction among pro-market economists and the ensuing debates hopelessly intertwined policy, models, and ideology. One could be sure that a model coming out of Yale would come to pro-government activist conclusions and a model coming out of Chicago would come to pro-market conclusions. It is highly unlikely that such models were "scientific" in any meaningful sense.

Our different interpretations of how ideology became embedded in science also affect our views of the role of rational choice theory in the process. Backhouse seems to accept Sonja Amadae's argument that rational choice theory provided an intellectual framework opposing communism. He argues that Kenneth Arrow's work on social choice showed that collectivism conflicted with liberal values, and that rational choice theory had ideological implications. I do not see it that way: those opposing communism or statism had no need for a formal scientific framework opposing communism; they could have relied on a variety of historical and philosophical arguments that had nothing to do with formal rational choice models. 
The final chapter in Part II deals with heterodoxy and dissent. It argues that organized dissent in economics has been largely ineffective, an assessment with which I agree. But the reason I see it as ineffective is that it too has blended policy and science, rather than separating the two.

The concluding chapter, "Economic science and economic myth", summarizes the argument of the book, and reiterates Backhouse's view that pro-market policy is based on a free-market myth. I agree that it is (although I prefer the term story to myth). But what Backhouse does not emphasize enough is that pro-government activist policy is also based on a pro-government myth. Unfortunately, the complexity of the economy means that reasonable stories are the best that we can do. My methodological prescription for the profession has been and continues to be that we should accept our limitations and base policy on the best stories we can develop. But to arrive at the best story, rather than to tell two separate stories, both sides have to admit that they are debating stories not science. Currently neither is willing to do so.

David Colander is the Christian A. Johnson distinguished professor of economics at Middlebury College, Vermont. He has long been interested in the sociology of the profession of economics and is the author of The making of an economist (with Arjo Klamer, Westview Press, 1990) and The making of an economist, redux (Princeton University Press, 2007). His recent research has particularly focused on extending the complexity approach to economics.

Contact e-mail: <colander@middlebury.edu>

Website: <http://community.middlebury.edu/ colander/index.html> 